Lingua Rima: Jurnal Pendidikan Bahasa dan Sastra Indonesia

Vol. 10 No. 3 September 2021

http://jurnal.umt.ac.id/index.php/lgrm

\title{
PENGARUH KEMAMPUAN MENULIS TEKS EKSPOSISI DENGAN MENGGUNAKAN METODE DISCOVERY LEARNING PADA SISWA KELAS VIII SMP MUHAMMADIYAH 1 KOTA TANGERANG
}

\author{
Enawar \\ Universitas Muhammadiyah Tangerang \\ enawar.abah @gmail.com
}

\begin{abstract}
ABSTRAK
Tujuan penelitian ini adalah untuk mengetahui perbedaan kemampuan menulis teks eksposisi pada siswa kelas VIII SMP Muhammadiyah 1 Kota Tangerang adalah pengajaran dengan menggunakan metode discovery learning. Penelitian ini menggunakan metode discovery learning pada kelas eksperimen dan tidak menggunakan metode discovery learning pada kelas kontrol. Pendekatan penelitian ini adalah kuantitatif dengan metode quasi eksperimental design. Bentuk quasi eksperimental design yang digunakan pada penelitian ini adalah bentuk Nonequivelent Control Group Design yang tidak dipilih secara acak karena alasan-alasan tertentu. Sampel dalam penelitian ini adalah siswa kelas VIII A dan VIII B VIII SMP Muhammadiyah 1 Kota Tangerang dengan jumlah sampel sebanyak 40 siswa yang terdiri dari 20 siswa untuk masing-masing kelas. Hasil penelitian menunjukkan bahwa pembelajaran dengan menggunakan metode discovery learning berpengaruh terhadap kemampuan menulis teks eksposisi siswa kelas VIII. Hal ini terbukti dari hasil uji hipotesis siswa yang tidak menggunakan metode discovery learning adalah $\mathrm{T}_{\text {hitung }}=0,458<\mathrm{T}_{\text {tabel }}=2,021$ dan uji hipotesis siswa yang menggunakan metode discovery learning adalah $\mathrm{T}_{\text {hitung }}=2,844>\mathrm{T}_{\text {tabel }}=$ 2,021. Dapat disimpulkan terdapat perbedaan kemampuan menulis teks eksposisi antara siswa yang diberi perlakuan dengan siswa yang tidak diberi perlakuan. Hasil penelitian ini diharapkan menjadi bahan informasi dan masukan bagi para mahasiswa/mahasiswi, para tenaga pengajar khususnya untuk bidang bahasa Indonesia. Serta mampu memotivasi siswa terhadap pembelajaran bahasa Indonesia, sehingga siswa dapat menjadi siswa yang berprestasi.
\end{abstract}

Kata kunci: discovery learning, menulis teks eksposisi.

\section{A. PENDAHULUAN}

Pembelajaran bahasa yang bertujuan untuk meningkatkan kemampuan berkomunikasi yang meliputi menyimak, berbicara, membaca, dan menulis. Keempat kemampuan merupakan hal yang tidak mudah untuk dicapai. Keempat kemampuan tersebut saling berkaitan satu sama lain dan memiliki kedudukan yang sama pentingnya dalam pembelajaran bahasa. Namun, dalam proses belajar mengajar di dalam kelas seringkali ditemui peserta didik yang masih rendah dalam keempat kemampuan tersebut, terutama dalam kemampuan menulisnya, karena menulis merupakan kemampuan yang paling tinggi tingkat kesulitannya.

Di zaman modern ini juga paradigma yang terjadi di sekolah khususnya dikalangan siswa kurang tertarik dan terbiasa untuk menulis, di antaranya menulis teks eksposisi pada pelajaran bahasa Indonesia, karena menganggap menulis merupakan kegiatan yang menjenuhkan. 


\section{Lingua Rima: Jurnal Pendidikan Bahasa dan Sastra Indonesia}

Vol. 10 No. 3 September 2021

http://jurnal.umt.ac.id/index.php/lgrm

Sehingga siswa tidak termotivasi dan kurang memiliki kemampuan dalam menulis karangan. Jika siswa diberikan soal untuk menjawab soal esai yang berhubungan dengan menulis karangan masih ada yang belum benar. Hal ini disebabkan siswa tidak terbiasa untuk menulis.

Menulis adalah salah satu dari 4 keterampilan berbahasa, yaitu: keterampilan menyimak, keterampilan berbicara, keterampilan membaca, dan keteampilan menulis. Dari keempat keterampilat tersebut, menulis merupakan keterampilan yang memiliki tingkat kesulitan yang tinggi. Menulis dikatakan memiliki tingkat kesulitan yang tinggi, karena ia merupakan kegiatan produktif dan ekspresif dalam berbahasa. Menulis merupakan suatu aktivitas yang dilakukan sebagai proses pengembangan diri. Aktivitas menulis tidak akan lepas dari proses belajar (Satrya, 2011: 8). Dalam proses pengembangan diri tentunya harus disertai dengan proses belajar. Yang mana proses ini dilakukan demi mencapai tujuan yang diinginkan, yaitu agar adanya progress di dalam diri seseorang.

Menurut Tarigan (2008:3) menulis merupakan "Suatu keterampilan berbahasa yang dipergunakan untuk berkomunikasi secara tidak langsung, tidak secara tatap muka dengan orang lain. Menulis merupakan suatu kegiatan yang produktif dan ekspresif'. Berarti, menulis adalah cara berkomunikasi yang dilakukan secara satu arah dengan menggunakan tulisan sebagai medianya. Jelasnya, penulis menyampaikan pikirannya dengan memproduksi kata-kata dan mengekspresikannya dalam sebuah tulisan, kemudian tulisan itu sampai kepada pembaca. Sama halnya dengan pendapat di atas, Kusmana (2012:99) mengatakan bahwa "Menulis dapat diartikan sebagai salah satu keterampilan berbahasa yang menuntut seseorang menghasilkan sesuatu (tulisan) sebagai ungkapan, perasaan, dan pemikirannya. Dengan demikian menulis merupakan keterampilan berbahasa untuk mengungkapkan pikiran, perasaan, keinginan ke dalam bentuk tulisan sebagai alat komunikasi tidak langsung. Di dalam tulisan ada pesan yang merupakan pemikiran penulis". Pesan di sini adalah maksud penulis yang berisi pikiran, perasaan, ataupun keinginannya yang disampaikan melalui tulisan.

Pada pembelajaran kita mengenal teks eksposisi Menurut Finoza (2008:246), "Kata eksposisi diambil dari kata Bahasa Inggris exposition sebenarnya berasal dari kata Bahasa Latin yang berarti 'membuka atau memulai'. Memang karangan eksposisi bertujuan untuk memberi tahu, mengupas, menguraikan, atau menerangkan sesuatu. Dengan demikian, sesuai dengan maknanya, maka teks eksposisi merupakan suatu teks yang bertujuan untuk memberi tahu atau membuka pengetahuan pembaca mengenai suatu topik. 


\section{Lingua Rima: Jurnal Pendidikan Bahasa dan Sastra Indonesia \\ Vol. 10 No. 3 September 2021 \\ http://jurnal.umt.ac.id/index.php/lgrm}

Keraf (2004:3) berpendapat bahwa, "Eksposisi atau pemaparan adalah salah satu bentuk tulisan atau retorika yang berusaha untuk menerangkan dan menguraikan suatu pokok pikiran, yang dapat memperluas pandangan atau pengertahuan seseorang yang membaca uraian tersebut. Berarti teks eksposisi merupakan suatu teks yang memaparkan suatu pokok pikiran untuk dapat dibaca oleh khalayak luas guna memperluas wawasan pembaca. Teks eksposisi adalah teks yang bertujuan untuk memberitahu pembaca atau menginformasikan suatu hal kepada pembaca. Informasi yang disampaikan dalam teks eksposisi dapat memperluas pengetahuan pembaca mengenai suatu pokok pikiran, namun informasi yang disampaikan dalam teks eksposisi tidak berusaha untuk mempengaruhi atau membujuk pembaca.

Selanjutnya dalam proses belajar mengajar kita mengenal istilah metode pengajaran menurut Roestiyah (2008:1) menyatakan bahwa metode pengajaran adalah "Teknik penyajian pelajaran adalah pengetahuan tentang cara-cara mengajar yang dipergunakan oleh guru atas instruktur. Pengertian lain ialah sebagai teknik penyajian yang dikuasai guru untuk mengajar atau menyajikan bahan pelajaran kepada siswa di dalam kelas, agar pelajaran tersebut dapat ditangkap, dipahami dan digunakan oleh siswa dengan baik. Menurut Suryosubroto (2013:140), "Salah satu tugas sekolah adalah memberikan pengajaran kepada anak didik. Mereka harus memperoleh kecakapan dan pengetahuan dari sekolah, di samping mengembangkan pribadinya. Pemberian kecakapan dan pengetahuan kepada murid-murid yang merupakan proses pengajaran (proses belajar mengajar) itu dilakukan oleh guru di sekolah dengan menggunakan cara-cara atau metode-metode tertentu. Cara-cara demikianlah yang dimaksudkan sebagai metode pengajaran di sekolah. Dengan demikian, metode pengajaran adalah cara-cara yang dilakukan guru untuk menyampaikan materi pembelajaran dalam proses belajar mengajar di sekolah.

Sehubungan dengan pendapat di atas, Surakhmad (Suryosubroto, 2013: 140) menegaskan bahwa "Metode pengajaran adalah cara-cara pelaksanaan daripada proses pengajaran, atau soal bagaimana teknisnya sesuatu bahan pelajaran diberikan kepada muridmurid di sekolah". Pendapat tersebut menyatakan bahwa pada dasarnya metode pengajaran adalah teknis pelaksanaan pembelajaran di sekolah untuk menyampaikan materi pembelajaran. Metode pengajaran adalah cara atau teknik dalam menyajikan materi pelajaran untuk diberikan kepada murid-murid di sekolah pada saat proses belajar mengajar berlangsung. Metode yang sesuai dengan pembelajaran menulis eksposisi yaitu menggunakan metode discovery learning karena metode ini siswa mampu memecahkan permasalahan secara Pengaruh Kemampuan Menulis Teks Eksposisi dengan Menggunakan Metode Discovery Learning pada Siswa Kelas VIII SMP Muhammadiyah 1 Kota Tangerang 
Lingua Rima: Jurnal Pendidikan Bahasa dan Sastra Indonesia

Vol. 10 No. 3 September 2021

http://jurnal.umt.ac.id/index.php/lgrm

aktif. Menurut Dewi, Silva dan Wikanengsih (2018) bahwa peserta didik membutuhkan model pembelajaran yang membuat peserta didik turut berpartisipasi aktif dalam pembelajaran sehingga mereka tidak mengalami kesulitan dalam menulis.

Oleh karena itu, penelitian ini bertujuan mengetahui perbedaan kemampuan menulis teks eksposisi pada siswa kelas VIII SMP Muhammadiyah 1 Kota Tangerang adalah pengajaran dengan menggunakan metode discovery learning. Penelitian sebelumnya dilakukan oleh Dewi, Silva dan Wikanengsih (2018) dengan judul Penerapan Metode Discovery Learning pada Pembelajaran Menulis Teks Eksposisi. Penelitian ini menghasilkan perbedaan yang signifikan antara sebelum dan sesudah menggunakan metode discovery learning. Berdasarkan data yang diperoleh diketahui adanya perbedaan dari tes awal dan tes akhir dengan rata-rata tes awal 48,7 dan tes akhir 79,0. Dilihat dari hasil rata-rata siswa yang meningkat dapat disimpulkan bahwa penggunaan metode Discovery Learning cocok digunakan dalam pembelajaran menulis teks eksposisi.

\section{B. METODE PENELITIAN}

Metode yang digunakan dalam penelitian ini adalah penelitian data kuantitatif. Jenis penelitian yang digunakan dalam penelitian ini adalah jenis penelitian quasi eksperimen dengan melakukan pretes dan postes. Menurut Sulaeman. (2019:168), “Quasi eksperimental design, digunakan karena pada kenyataannya sulit mendapatkan kelompok kontrol yang digunakan untuk penelitian. Maksud dari kelompok kontrol yaitu kelompok yang tidak mendapatkan perlakuan. Metode penelitian quasi eksperimen ini menggunakan desain penelitian Nonequivalent Control Group Design yang hampir sama dengan Pretest-Postest Control Group Design, hanya pada desain ini kelompok eksperimen maupun kelompok kontrol tidak dipilih secara acak. Sampel dalam penelitian ini adalah siswa kelas VIII A dan VIII B VIII SMP Muhammadiyah 1 Kota Tangerang dengan jumlah sampel sebanyak 40 siswa yang terdiri dari 20 siswa untuk masing-masing kelas. Teknik pengambilan data menggunakan tes yaitu pretest dan postest. Teknik analisis data menggunakan uji homogenitas dan uji hipotesis.Uji homogenitas dilakukan untuk mengetahui apakah data hasil penelitian kedua kelompok sampel memiliki varians yang sama atau tidak. Jika kedua kelompok memiliki varians yang sama, maka dikatakan bahwa kedua kelompok sampel homogen. Pasangan hipotesis yang akan diuji adalah sebagai berikut:

$\mathrm{H}_{0}: \sigma_{1}{ }^{2}=\sigma_{2}{ }^{2}$, artinya kedua kelompok sampel mempunyai varians sama.

$\mathrm{H}_{1}: \sigma_{1}^{2} \neq \sigma_{2}^{2}$, artinya kedua kelompok sampel tidak mempunyai varians sama. 
Lingua Rima: Jurnal Pendidikan Bahasa dan Sastra Indonesia

Vol. 10 No. 3 September 2021

http://jurnal.umt.ac.id/index.php/lgrm

Uji hipotesis ini digunakan untuk mengetahui perbedaan kondisi sebelum dan setelah perlakuan kelompok tidak saling berpasangan. Jenis data yang digunakan harus berskala interval atau rasio. Terdapat dua rumus uji t untuk sampel independen yaitu the separate model t-test dan the pooled variance model $t$-test. Peneliti menggunakan dua rumus tersebut dengan ketentuan sebagai berikut:

1) The Separate Model T-test

$$
\begin{aligned}
& \mathrm{t}=\frac{\bar{X} 1-\bar{X} 2}{\sqrt{\frac{S_{1}^{2}}{n 1}+\frac{S_{2}^{2}}{n 2}}} \quad \text { (Riadi, 2014, h. 159) } \\
& \mathrm{n} 1=\mathrm{n} 2 \text { sampel homogen } \leftrightarrow \mathrm{dk}=\mathrm{n} 1+\mathrm{n} 2-2 \\
& \mathrm{n} 1=\mathrm{n} 2 \text { sampel tidak homogen } \leftrightarrow \mathrm{dk}=\mathrm{n} 1-1 \text { atau } \mathrm{n} 2-1 \\
& \mathrm{n} 1 \neq \mathrm{n} 2 \text { sampel tidak homogen } \leftrightarrow \mathrm{t}_{\text {tabel }}=\left(\Delta \mathrm{t}_{\text {tabel }} / 2\right)+\mathrm{t}_{\text {tabel }} \text { terkecil } \quad\left(\Delta \mathrm{t}_{\text {tabel }}=\text { selisih } \mathrm{t}_{\text {tabel }}\right. \\
& \text { keterangan: }
\end{aligned}
$$

$\bar{x}_{1}=$ nilai rata-rata kelompok eksperimen 1

$\bar{x}_{2}=$ nilai rata-rata kelompok eksperimen 2

$\bar{s}_{1}=$ varians sampel kelompok eksperimen 1

$\bar{S}_{2}=$ varians sampel kelompok eksperimen 2

$\bar{n}_{1}=$ jumlah responden kelompok eksperimen 1

$\bar{n}_{2}=$ jumlah responden kelompok eksperimen 2

2) The Pooled Variance Model T-test

$$
\begin{aligned}
& \mathrm{t}=\frac{\bar{X} 1-\bar{X} 2}{\sqrt{\frac{(n 1-1) S_{1}^{2}+(n 2-1) S_{1}^{2}}{n 1+n 2-2}}}\left(\frac{1}{n_{1}}+\frac{1}{n_{2}}\right) \text { (Riadi, 2014: 159) } \\
& \text { Jika } \mathrm{n} 1=\mathrm{n} 2 \text { sampel homogen } \leftrightarrow \mathrm{dk}=\mathrm{n} 1+\mathrm{n} 2-2 \\
& \quad \mathrm{n} 1 \neq \mathrm{n} 2 \text { sampel homogen } \leftrightarrow \mathrm{dk}=\mathrm{n} 1+\mathrm{n} 2-2 \\
& \mathrm{n} 1=\mathrm{n} 2 \text { sampel homogeny } \leftrightarrow \mathrm{dk}=(\mathrm{n} 1-1) \text { atau }(\mathrm{n} 2-1)
\end{aligned}
$$

Keterangan:

$\mathrm{T}=$ nilai $\mathrm{t}$

$\bar{x}_{1}=$ nilai rata-rata kelompok eksperimen 1

$\bar{x}_{2}=$ nilai rata-rata kelompok eksperimen 2

$\bar{s}_{1}=$ varians sampel kelompok eksperimen 1

$\bar{s}_{2}=$ varians sampel kelompok eksperimen 2

$\bar{n}_{1}=$ jumlah responden kelompok eksperimen 1

$\bar{n}_{2}=$ jumlah responden kelompok eksperimen 2

Pengujian dengan menggunakan t-test berkorelasi uji dua pihak. Menggunakan uji dua pihak karena hipotesis $\left(\mathrm{H}_{1}\right)$ berbunyi terdapat perbedaan, sedangkan hipotesis $\left(\mathrm{H}_{0}\right)$ berbunyi tidak terdapat perbedaan. Setelah dilakukan t-test, maka untuk mengetahui perbedaan itu signifikan atau tidak maka harga $t_{\text {hitung }}$ tersebut perlu dibandingkan dengan $t_{\text {tabel }}$ dengan $\mathrm{dk}=$ n1+n2-2 dan taraf kepercayaan 95\%. Kriteria pengujian untuk daerah penerimaan dan penolakan hipotesis adalah sebagai berikut: 
Lingua Rima: Jurnal Pendidikan Bahasa dan Sastra Indonesia

Vol. 10 No. 3 September 2021

http://jurnal.umt.ac.id/index.php/lgrm

Tolak $\mathrm{H}_{1}$, dan terima $\mathrm{H}_{0}$, jika:

$t_{\text {hitung }}>t_{\text {tabel }}$

Terima $\mathrm{H}_{0}$ dan tolak $\mathrm{H}_{1}$, jika:

$t_{\text {hitung }}<t_{\text {tabel }}$

Hipotesis yang diajukan adalah:

$H_{o}$ : Tidak terdapat perbedaan berfikir kritis antara siswa yang mendapat metode pembelajaran discovery learning dan siswa yang tidak mendapat perlakuan.

$H_{1}$ : Terdapat perbedaan berfikir kritis antara siswa yang mendapat metode pembelajaran discovery learning dan siswa yang tidak mendapat perlakuan.

Kriteria uji :

Dengan membandingkan $T_{1}$ dengan $T_{2}$. Kemudian dipilih nilai yang terkecil antara $T_{1}$ dengan $\mathrm{T}_{2}$ dan dijadikan $\mathrm{T}_{\text {hitung }}$ untuk kemudian dibandingkan dengan $\mathrm{T}_{\text {tabel. }}$

Ho ditolak jika, $\mathrm{T}_{\text {hitung }}<\mathrm{T}_{\text {tabel }}$ maka Terdapat perbedaan berfikir kritis antara siswa yang mendapat metode pembelajaran discovery learning dan siswa yang tidak mendapat perlakuan.

Ho diterima jika, $\mathrm{T}_{\text {hitung }}>\mathrm{T}_{\text {tabel }}$ maka, Tidak terdapat perbedaan berfikir kritis antara siswa yang mendapat metode pembelajaran discovery learning dan siswa yang tidak mendapat perlakuan.

\section{HASIL DAN PEMBAHASAN}

\section{Hasil Pengujian Prasyarat Analisis Data}

\section{Analisis Data Pre-test}

Analisis data dilakukan bertujuan untuk mengetahui kemampuan awal siswa dan kesetaraan dua kelompok yang sedang diteliti, yaitu kelas eksperimen dan kelas kontrol.

\section{a. Uji Normalitas}

Uji normalitas yang digunakan dalam penelitian ini dengan Liliefors. dalam pengujian normalitas data pretes adalah:

$\mathrm{H}_{0}=$ Data berdistribusi normal

$\mathrm{H}_{1}=$ Data tidak berdistribusi normal

Dengan menggunakan taraf signifikansi $\alpha=0,05$ maka kriteria pengujian adalah:

Dengan kriteria perhitungan sebagai berikut :

Jika $\mathrm{L}_{\text {hitung }} \leq \mathrm{L}_{\text {tabel }}$, maka $\mathrm{H}_{0}$ diterima 
Lingua Rima: Jurnal Pendidikan Bahasa dan Sastra Indonesia

Vol. 10 No. 3 September 2021

http://jurnal.umt.ac.id/index.php/lgrm

Jika $\mathrm{L}_{\text {hitung }}>\mathrm{L}_{\text {tabel }}$, maka $\mathrm{H}_{0}$ ditolak

Dari hasil pengujian data pretes diperoleh hasil sebagai berikut:

Tabel 4.19

Perhitungan Liliefors Pretes

\begin{tabular}{|c|c|c|c|}
\hline Kelompok & $\mathbf{L}_{\text {Tabel }}$ & $\mathbf{L}_{\text {Hitung }}$ & \multirow{2}{*}{ Berdistribusi } \\
Eksperimen & 0,190 & 0,128 & Normal \\
\cline { 1 - 3 } Kontrol & 0,190 & 0,178 & \\
\hline
\end{tabular}

Terlihat bahwa $\mathrm{L}_{\text {Hitung }}$ kelas eksperimen lebih kecil dari $\mathrm{L}_{\text {Tabel }}$ yaitu $0,128<0,190$, berdasarkan kriteria uji normalitas dengan uji liliefors jika Jika $\mathrm{L}_{\text {hitung }} \leq \mathrm{L}_{\text {tabel }}$, maka $\mathrm{H}_{0}$ diterima, sehingga sampel berdistribusi normal. Demikian juga kelas kontrol, terlihat bahwa nilai $\mathrm{L}_{\text {Hitung }}$ kelas kontrol lebih kecil dari $\mathrm{L}_{\text {Tabel }}$ yaitu 0,178 $<0,190$, berdasarkan uji normalitas dengan menggunakan uji liliefors jika Jika $\mathrm{L}_{\text {hitung }} \leq \mathrm{L}_{\text {tabel }}$, maka $\mathrm{H}_{0}$ diterima. Jadi dapat disimpulkan bahwa kedua kelas eksperimen dan kontrol berasal dari data yang berdistribusi normal.

\section{b. Uji Homogenitas}

Uji homogenitas dilakukan untuk mengetahui apakah data dari masingmasing kelompok memiliki varians populasi yang sama atau berbeda. Dalam menguji homogenitas dalam penelitian ini menggunakan rumus uji F. Hipotesis dalam pengujian homogenitas dirumuskan sebagai berikut:

$\mathrm{H}_{\mathrm{o}}$ : Varians kedua sampel homogen

$\mathrm{H}_{\mathrm{a}}$ : Varians kedua sampel tidak homogen

Dengan taraf ignifikasni $\alpha=0,05$, maka kriteria pengujiannya adalah:

Dengan kriteria pengujian adalah :

Jika $F_{\text {hitung }} \leq F_{\text {tabel }}$, maka terima $\mathrm{H}_{\mathrm{o}}$ (varians kedua sampel homogen)

Jika $F_{\text {hitung }}>F_{\text {tabel }}$, maka tolak $\mathrm{H}_{\mathrm{o}}$ (varians kedua sampel tidak homogen)

Dari hasil pengujian data diperoleh data sebagai berikut:

Tabel 4.20

Perhitungan Homogenitas

\begin{tabular}{|c|c|c|}
\hline $\mathrm{F}_{\text {hitung }}$ & $\mathrm{F}_{\text {tabel }}$ & Varians Data \\
\hline
\end{tabular}

Pengaruh Kemampuan Menulis Teks Eksposisi dengan Menggunakan Metode Discovery Learning pada Siswa Kelas VIII SMP Muhammadiyah 1 Kota Tangerang 
Lingua Rima: Jurnal Pendidikan Bahasa dan Sastra Indonesia

Vol. 10 No. 3 September 2021

http://jurnal.umt.ac.id/index.php/lgrm

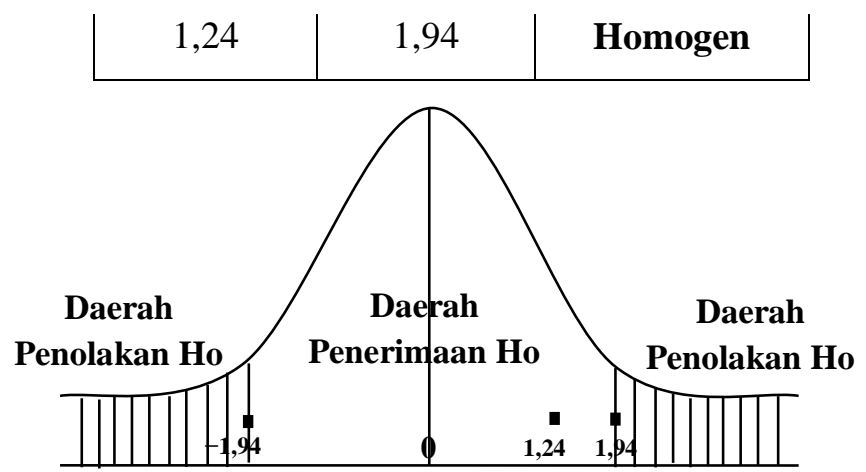

Terlihat pada tabel di atas bahwa $F_{\text {hitung }}$ lebih kecil dari $F_{\text {tabel }}$, menurut kriteria uji homogenitas jika $\mathrm{F}_{\text {hitung }}<\mathrm{F}_{\text {tabel }}$ maka $\mathrm{H}_{\mathrm{o}}$ diterima, kemudian digambarkan pada kurva bahwa 1,24 berada pada daerah penerimaan Ho. Sehingga berdasarkan kriteria pengujian diatas maka varians kedua sampel homogen.

\section{Analisis Data Postes}

\section{a. Uji Normalitas}

Uji normalitas yang digunakan dalam penelitian ini dengan Liliefors. dalam pengujian normalitas data postes adalah:

$\mathrm{H}_{0}=$ Data berdistribusi normal

$\mathrm{H}_{1}=$ Data tidak berdistribusi normal

Dengan menggunakan taraf signifikansi $\alpha=0,05$ maka kriteria pengujian adalah:

Dengan kriteria perhitungan sebagai berikut :

Jika $\mathrm{L}_{\text {hitung }} \leq \mathrm{L}_{\text {tabel}}$, maka $\mathrm{H}_{0}$ diterima

Jika $\mathrm{L}_{\text {hitung }}>\mathrm{L}_{\text {tabel }}$, maka $\mathrm{H}_{0}$ ditolak

Dari hasil pengujian data postes diperoleh hasil sebagai berikut:

Tabel 4.21

Perhitungan Liliefors Postes

\begin{tabular}{|c|c|c|c|}
\hline Kelompok & $\mathbf{L}_{\text {Tabel }}$ & $\mathbf{L}_{\text {Hitung }}$ & \multirow{2}{*}{ Berdistribusi } \\
Eksperimen & 0,190 & 0,161 & \multirow{2}{*}{ Normal } \\
\cline { 1 - 3 } Kontrol & 0,190 & 0,165 & \\
\hline
\end{tabular}

Berdasarkan tabel di atas terlihat bahwa $\mathrm{L}_{\text {Hitung }}$ kelas eksperimen lebih kecil dari $\mathrm{L}_{\text {Tabel }}$ yaitu $0,161<0,190$, menurut kriteria normalitas dengan pengujian uji liliefors jika Jika $\mathrm{L}_{\text {hitung }} \leq \mathrm{L}_{\text {tabel}}$, maka $\mathrm{H}_{0}$ diterima, sehingga berdasarkan kriteria pengujian maka sampel berdistribusi normal. Demikian juga kelas kontrol, terlihat 
Lingua Rima: Jurnal Pendidikan Bahasa dan Sastra Indonesia

Vol. 10 No. 3 September 2021

http://jurnal.umt.ac.id/index.php/lgrm

bahwa nilai $\mathrm{L}_{\text {Hitung }}$ kelas kontrol lebih kecil dari $\mathrm{L}_{\text {Tabel }}$ yaitu $0,165<0,190$, menurut kriteria normalitas dengan pengujian menggunakan liliefors jika $\mathrm{L}_{\mathrm{hitung}} \leq$ $\mathrm{L}_{\text {tabel}}$, maka $\mathrm{H}_{0}$ diterima, jadi dapat disimpulkan bahwa kedua kelas eksperimen dan kontrol berasal dari data yang berdistribusi normal.

\section{b. Uji Homogenitas}

Uji homogenitas dilakukan untuk mengetahui apakah data dari masing-masing kelompok memiliki varians populasi yang sama atau berbeda. Dalam menguji homogenitas dalam penelitian ini menggunakan rumus uji F. Hipotesis dalam pengujian homogenitas dirumuskan sebagai berikut:

$\mathrm{H}_{\mathrm{o}}$ : Varians kedua sampel homogen

$\mathrm{H}_{\mathrm{a}}$ : Varians kedua sampel tidak homogen

Dengan taraf ignifikasni $\alpha=0,05$, maka kriteria pengujiannya adalah:

Dengan kriteria pengujian adalah :

Jika $F_{\text {hitung }} \leq F_{\text {tabel }}$, maka terima $\mathrm{H}_{\mathrm{o}}$ (varians kedua sampel homogen)

Jika $F_{\text {hitung }}>F_{\text {tabel }}$, maka tolak $\mathrm{H}_{\mathrm{o}}$ (varians kedua sampel tidak homogen)

Dari hasil pengujian data diperoleh data sebagai berikut:

Tabel 4.22

Perhitungan Homogenitas

\begin{tabular}{|c|c|c|}
\hline $\mathrm{F}_{\text {hitung }}$ & $\mathrm{F}_{\text {table }}$ & Varians Data \\
\hline 1,07 & 1,94 & Homogen \\
\hline
\end{tabular}
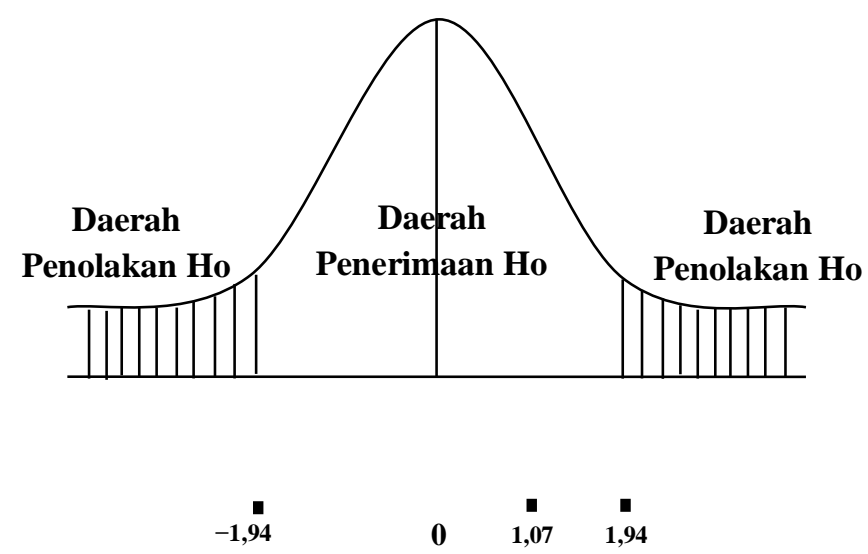


\section{Lingua Rima: Jurnal Pendidikan Bahasa dan Sastra Indonesia \\ Vol. 10 No. 3 September 2021 \\ http://jurnal.umt.ac.id/index.php/lgrm}

Berdasarkan tabel di atas terlihat bahwa $\mathrm{F}_{\text {hitung }}$ lebih kecil dari $\mathrm{F}_{\text {tabel }}$, menurut kriteria homogenitas jika $\mathrm{F}_{\text {hitung }} \leq \mathrm{F}_{\text {tabel }}$ maka $\mathrm{H}_{\mathrm{o}}$ diterima, digambarkan pula pada kurva di atas bahwa 1,07 berada dalam daerah penerimaan Ho. Sehingga berdasarkan kriteria pengujian diatas maka varians kedua sampel homogen.

\section{Pembahasan Penelitian}

Berdasarkan perhitungan data hasil penelitian pretes, diperoleh nilai terendah di kelas kontrol yaitu (40), dan nilai terendah di kelas eksperimen yaitu (40). Adapun nilai terbesar di kelas kontrol adalah (73), dan nilai terbesar di kelas eksperimen yaitu (73). Adapun nilai ratarata pretes kelas kontrol yaitu $(57,66)$, dan nilai rata-rata kelas eksperimen yaitu (59). Dari data hasil penelitian pretes kemampuan menulis teks eksposisi antara kelas kontrol dan kelas eksperimen tidak memiliki perbedaan yang signifikan, meskipun nilai rata-rata kelas eksperimen lebih tinggi jika dibandingkan dengan nilai rata-rata kelas kontrol. Hasil dari uji hipotesis data pretes menunjukkan $\mathrm{t}_{\text {hitung }}=0,458<\mathrm{t}_{\text {tabel }}=2,021$, maka sesuai dengan pendapat di atas bahwa pada penelitian data pretes tidak terdapat perbedaan yang signifikan terhadap kemampuan menulis teks eksposisi.

Pembelajaran yang menggunakan metode discovery learning di kelas eksperimen mendapatkan nilai rata-rata lebih tinggi dari pada kelas kontrol yang tidak menggunakan metode discovery learning. Hal ini didukung dengan metode yang digunakan, karena pembelajaran dengan menggunakan metode discovery learning siswa dapat lebih fokus dan berperan aktif selama proses pembelajaran berlangsung. Siswa juga dapat bertanya-jawab mengenai permasalahan-permasalahan tertentu yang mereka hadapi, dengan begitu siswa dapat lebih mudah untuk menulis teks eksposisi.

Berbeda dengan kelas kontrol yang tidak diberikan perlakuan. Di kelas kontrol ini, selama pembelajaran berlangsung guru hanya menjelaskan materi yang akan dipelajari. Siswa di kelas kontrol pun hanya mendengarkan dan mencatat apa yang disampaikan guru, sehingga siswa menjadi pasif dalam proses pembelajaran. Ketika guru memberikan tugas untuk membuat karangan eksposisi, maka siswa pun membuatnya tanpa dapat berdiscovery learning dengan teman-temannya.

Berdasarkan perhitungan data hasil penelitian postes, diperoleh nilai terendah di kelas kontrol yaitu (53), dan nilai terendah di kelas eksperimen yaitu (60). Adapun nilai terbesar di kelas kontrol adalah (86), dan nilai terbesar di kelas eksperimen yaitu (93). Adapun nilai ratarata postes kelas kontrol yaitu $(68,66)$, dan nilai rata-rata postes kelas eksperimen yaitu $(76)$. 


\section{Lingua Rima: Jurnal Pendidikan Bahasa dan Sastra Indonesia \\ Vol. 10 No. 3 September 2021 \\ http://jurnal.umt.ac.id/index.php/lgrm}

Dari data hasil penelitian postes kemampuan menulis teks eksposisi antara kelas kontrol dan kelas eksperimen terdapat perbedaan yang signifikan. Hasil dari uji hipotesis data postes menunjukkan $t_{\text {hitung }}=2,844>t_{\text {tabel }}=2,021$ dengan demikian, maka terdapat perbedaan yang signifikan antara kelas kontrol dan kelas eksperimen.

Maka disimpulkan bahwa hasil dalam penelitian ini terdapat pengaruh penggunaan metode discovery learning terhadap kemampuan menulis teks eksposisi. Penggunaan metode ini mampu meningkatkan kemampuan menulis teks eksposisi siswa. Akan tetapi, penulis menyadari bahwa penelitian ini tidak terlepas dari kekurangan, keterbatasan, dan tidak sepenuhnya mencapai tingkat kebenaran mutlak. Penyebabnya adalah keterbatasan waktu, biaya, dan kemampuan peneliti dalam melakukan penelitian lebih dalam lagi. Dengan demikian, peneliti berharap ada peneliti berikutnya yang dapat meneliti dengan tinjauan lebih luas.

\section{SIMPULAN DAN SARAN}

Berdasarkan analisis data skor pretes kemampuan menulis teks eksposisi siswa kelas VIII SMP Muhammadiyah 1 Kota Tangerang menunjukan nilai rata-rata kelas eksperimen adalah 59 dan nilai rata-rata kelas kontrol adalah 57,66, maka didapatkan $t_{\text {hitung }}$ lebih kecil dari $t_{\text {tabel }}$ dimana $t_{\text {hitung }}$ adalah 0,458 dan $t_{\text {tabel }}$ adalah 2,021 sehingga Ho diterima, maka dapat disimpulkan bahwa tidak terdapat perbedaan kemampuan rata-rata kemampuan menulis teks eksposisi siswa antara kelas kontrol dan eksperimen. Hal ini menunjukan bahwa kondisi awal kelas eksperimen dan kelas kontrol sebelum dilakukan penelitian sama-sama tidak mencapai nilai KKM.

Berdasarkan analisis terhadap data skor postes kemamapuan menulis teks eksposisi siswa kelas VIII SMP Muhammadiyah 1 Kota Tangerang menunjukkan nilai rata-rata kelas eksperimen adalah 76 dan nilai rata-rata kelas kontrol adalah 68,66. Analisis uji-t menunjukkan jumlah rata-rata kelas eksperimen lebih besar dibanding kelas kontrol, sehingga didapatkan $\mathrm{t}_{\text {hitung }}$ lebih besar dari $\mathrm{t}_{\text {tabel }}$ dimana $\mathrm{t}_{\text {hitung }}$ adalah 2,844 dan $\mathrm{t}_{\text {tabel }}$ adalah 2,021 maka Ho ditolak, dengan demikian dapat disimpulkan bahwa terdapat perbedaan kemampuan menulis teks eksposisi siswa antara siswa yang mendapat pembelajaran dengan metode discovery learning dan siswa yang tidak mendapat pembelajaran dengan metode discovery learning.

Berdasarkan hasil penelitian yang telah diperoleh guru hendaknya menggunakan metode pembelajaran yang tepat dalam proses pembelajaran. Pemilihan metode yang bervariasi maka Pengaruh Kemampuan Menulis Teks Eksposisi dengan Menggunakan Metode Discovery Learning pada Siswa Kelas VIII SMP Muhammadiyah 1 Kota Tangerang 
Lingua Rima: Jurnal Pendidikan Bahasa dan Sastra Indonesia

Vol. 10 No. 3 September 2021

http://jurnal.umt.ac.id/index.php/lgrm

siswa akan termotivasi dan dapat membantu dalam merangsang siswa untuk mengikuti kegiatan pembelajaran. Selain itu, siswa pun dapat lebih tertarik dan dapat berperan aktif selama proses pembelajaran berlangsung. Siswa hendaknya lebih bersemangat dalam belajar dan dapat berperan aktif dalam proses pembelajaran demi menambah pengetahuan dan meningkatkan hasil belajar.

\section{E. DAFTAR PUSTAKA}

Dewi, U. K., Silvia, P. S, dan Wikanengsih. (2018). Penerapan Metode Discovery Learning pada Pembelajaran Menulis Teks Eksposisi. Jurnal Parole. Vol 1 No 6 Hal 10211028

Finoza, L. (2008). Komposisi Bahasa Indonesia. Jakarta: Diksi.

Keraf, G. (2004). Deskripsi dan Eksposisi. Jakarta: Gramedia Pustaka Utama.

Kusmana, S. (2012). Guru Bahasa Indonesia Profesional. Jakarta: Multi Kreasi Satudelapan.

Roestiyah, N.K. (2008). Strategi Belajar Mengajar. Jakarta: Rineka Cipta.

Satrya, D. G. (2011). Creative Writing. Jakarta: PT Prestasi Pustakaraya.

Sulaeman, A, dan Goziyah. (2019). Metodologi Penelitian Pendidikan Bahasa dan Sastra. Edu Pustaka; Jakarta.

Suryosubroto, B. (2013). Proses Belajar Mengajar di Sekolah. Jakarta: Rineka Cipta.

Tarigan, H. G. (2008). Menulis Sebagai Suatu Keterampilan Berbahasa. Bandung: Angkasa. 